\title{
STUDI PERBEDAAN PERSIAPAN BAHAN BAKU SURIMI TERHADAP KUALITAS SENSORIK DAN KIMIA SOSIS IKAN BANDENG (Chanos chanos Forsskal)
}

\author{
Wa Endang*, Andi Besse Patadjai, Kobajashi T. Isamu \\ Jurusan Teknologi Hasil Perikanan Fakultas Perikanan dan Ilmu Kelautan Universitas Halu Oleo, Jalan H.E.A \\ Mokodompit Kampus Bumi Tridharma Anduonohu, Kendari 93232 Sulawesi Tenggara \\ Telepon +6282191328764 \\ *Korespondensi: endang fishteck@yahoo.com \\ Diterima: 27 September/ Disetujui: 14 Oktober 2018
}

Cara sitasi: Endang W, Patadjai AB, Isamu KT. 2018. Studi perbedaan persiapan bahan baku surimi terhadap kualitas sensorik dan kimia sosis ikan bandeng (Chanos chanos Forsskal). Jurnal Fish Protech. 1(2):124-133

\begin{abstract}
Abstrak
Penelitian ini bertujuan untuk menentukan pengaruh persiapan bahan baku surimi yang berbeda pada kualitas sensoris dan kimia sosis ikan bandeng (Chanos chanos Forsskal). Pada penelitian ini terdapat tiga metode persiapan bahan baku yang digunakan sebagai bahan baku sosis ikan yaitu 100\% surimi sebagai perlakuan S1; 50\% surimi : 50\% daging ikan cincang sebagai perlakuan S2; dan 100\% daging ikan cincang sebagai perlakuan S3. Kualitas bahan baku ditentukan dengan uji lipat dan uji gigit, sedangkan untuk sosis ikan dilakukan analisis sensorik dan analisis proksimat. Data yang dikumpulkan dianalisis secara deskriptif. Berdasarkan hasil penelitian yang diperoleh menunjukan bahwa perlakuan $100 \%$ surimi (S1) diperoleh hasil uji sensorik aroma 5,4, odor 6,7, warna 5,25, berongga 4,9, shiness 5,4, kekenyalan 5,5, hardness 2,4, Juiceness 5,6, umami 6. Sedangkan hasil analisis kimia dari perlakuan (S3) berdasarkan berat kering diperoleh hasil kadar air, abu, lemak, protein berturut-turut yakni 58,96, 6,22\%, 19,12\%, 48,6\%.
\end{abstract}

Kata Kunci : Bahan baku, Surimi, Sensorik, Sosis

\section{STUDY ON DIFFERENCES IN RAW MATERIAL PREPARATION OF SURIMI ON THE SENSORY AND CHEMICAL QUALITY OF MILKFISH (Chanos chanos Forrskal) SAUSAGE}

\begin{abstract}
This study aims to determine the effect of different raw material preparation of surimi on sensory and chemical qualities of milkfish (Chanos chanos Forsskal) sausage. There were three treatmen based on preparation surimi method used as fish sausage raw material i.e; 100 $\%$ surimi as treatment $\mathrm{S} 1 ; 50 \%$ surimi : $50 \%$ minced fish meat as treatment $\mathrm{S} 2$; and $100 \%$ minced fish meat as treatment S3. The quality of raw material was determine by folding test and teeth cutting test, while for fish sausage by sensories and proximate analysis. Data gathered was analyzed descriptive. Based on the result was found that the addition of treatment $100 \%$ surimi (S1) was obtained by sensory scent test of 5,4 ; odor 6,7 ; color 5,25 ; texture 4,9; shiness 5,4; jellynity 5,5; hardness 2,4; juiceness 5,6; umami 6. \%. While the chemical quality analysis of the treatment (S3) based on dry weight was obtained result of water content, ash, fat, protein respectively that is $58,96 \%, 6,22 \%, 19,12 \%$, and $48,6 \%$.
\end{abstract}

Keywords : Raw material, surimi, sensory, sausage 


\section{PENDAHULUAN}

Ikan sebagai salah satu sumber protein hewani mengandung semua jenis asam amino esensial yang diperlukan oleh tubuh manusia (Suhartini dan Hidayat, 2005). Salah satu komoditas perikanan yang memilki peluang sangat besar untuk dikembangkan dalam rangka pemenuhan gizi masyarakat. Menurut USDA National Nutrient Databased For Standar Reference (2013), ikan bandeng mengandung $20,53 \%$ protein dan $6,73 \%$ lemak sehingga digolongkan ikan protein tinggi dan berlemak sedang (Junianto, 2003). Lemak pada ikan bandeng merupakan sumber asam lemak tak jenuh (Agustini et al., 2010). Keistimewaan nilai gizi ikan bandeng segar terlihat seperti yang dinyatakan oleh (Irianto dan Soesilo, 2007) yaitu omega-3 sebesar 19,56; omega-6 sebesar 7,47; dan omega-9 sebesar 19,24. Akan tetapi, selain memiliki kandungan gizi yang cukup tinggi ikan bandeng juga memiliki kelemahan yang kurang diminati olah masyarakat yaitu memiliki banyak duri pada dagingnya. Kelemahan lain sebagai spesies perairan ikan bandeng termaksud komoditas yang cepat rusak bahkan lebih cepat dibandingkan dengan daging hewan lainnya.

Berbagai upaya perlu dilakukan untuk meningkatkan konsumsi ikan salah satunya dengan diversifikasi pengolahan hasil perikanan. Pengembangan dalam pengolahan produk-produk perikanan diperlukan bahan baku yang bermutu tinggi salah satunya adalah dalam bentuk surimi. Bahan baku dalam bentuk surimi ini, daging ikan disiapkan untuk mudah digunakan dalam berbagai macam bentuk olahan berbasis ikan maupun untuk diversifikasi, mudah disimpan, tahan lama dalam bentuk mirip daging ikan segar mempunyai nilai gizi yang menyehatkan (Guenneugues dan Morryssey, 2005 dalam Martin Sanchez et al., 2009). Selain itu keunggulan surimi adalah dapat diolah menjadi macam produk lanjutan (Rostini,
2013). Salah satu lanjutan pengolahan surimi adalah sebagai produk sosis ikan.

Sosis merupakan makanan asing yang sudah akrab dalam kehidupan masyarakat Indonesia karena rasanya enak. Menurut Widodo (2008), ikan kurisi dengan penambahan keragenan $1 \%$ dan isolat protein $1 \%$ berdasarkan uji sensorik sosis ikan yang paling disukai oleh panelis sedangkan dari uji fisik memiliki karakteristik hampir sama dengan sosis ikan komersil yang ada di pasaran. Sosis ikan lele dumbo pada perlakuan dengan konsentrasi asap cair $20 \%$ dan lama perendaman 30 menit kadar air $62,56 \%$, kadar lemak 12,33\% kadar fenol 292,74 ppm (Ernawati, 2015).

Berdasarkan latar belakang diatas maka perlu dilakukan penelitian tentang "Studi perbedaan persiapan bahan baku daging ikan lumat terhadap kualitas sensorik dan kimia sosis ikan bandeng (Chanos chanos Forsskal)".

\section{Bahan dan Alat}

\section{METODE PENELITIAN}

Bahan utama untuk pembuatan sosis terdiri dari daging ikan cincang, surimi, bawang putih, jahe, pala, minyak goreng, putih telur, garam, gula, merica, es batu dan STPP (Sodium tripolyphosphate). Alat yang digunakan dalam penelitian ini terdiri dari meat bone separator Maksindo tipe ZU-200, kain saring, termometer, suffer tipe SSF SH7, silent cutter Maksindo Tipe mesin QS620B, timbangan analitik, selonsong dan plastik Poliethylene (PE).

\section{Rancangan Penelitian}

Tiga jenis bahan baku yang digunakan yang sebagai bahan uji yang ditentukan kualitas sensorik dan kimia. Ketiga jenis perlakuan tersebut adalah 100\% surimi, 50\% surimi : 50\% daging ikan cincang dan $100 \%$ daging ikan cincang. Untuk uji sensorik menggunakan 20 orang panelis yang sekaligus bertujuan sebagai blok. Analisis data sensorik menggunakan analisis statistik non 
parametrik metode krusskal wallis untuk mengetahui perbedaan masing-masing perlakuan pada bahan baku terhadap kualitas sensorik sosis ikan. Apabila terdapat pengaruh yang signifikan maka dilakukan uji lanjut Mann-whitney U Test untuk mengetahui perbedaan antar perlakuan dengan taraf kepercayaan $\alpha=$ 0,05 . Analisis data proksimat dianalisis secara deskritif.

\section{Pembuatan Daging Ikan Cincang dan Surimi}

Ikan yang digunakan dalam penelitian ini diperoleh dari tambak ikan bandeng yang terdapat didaerah Anduonohu Kota Kendari. Kemudian dilakukan penyimpanan ikan dalam cool box dengan suhu chiling. Penimbangan ikan bandeng dan proses penyiangan untuk menghilangkan kepala, sisik dan jeroan. Membelah ikan membentuk split dan dilakukan pencucian dengan air es untuk menghilangkan kotoran dan darah. Selanjutnya memasukan ikan kedalam meat bone separator secara bergantian untuk memisahkan daging dan tulang (deboning) sehingga diperoleh daging ikan cincang dari proses pemisahan tersebut.

Untuk pembuatan surimi dilanjutkan dengan menggunakan air $\left(7^{\circ} \mathrm{C}\right)$ dengan perbandingan 4:1 (air : daging ikan cincang) dan dilakukan penambahan garam sebanyak $3 \% \mathrm{v} / \mathrm{w}$ pada pencucian terakhir. Proses pencucian surimi dilakukan pada suhu dingin $\left(5-10^{\circ} \mathrm{C}\right)$ dengan pengadukan selama kurang lebih 10 menit. Daging ikan lumat yang telah dilakukan pencucian kemudian disaring menggunakan kain saring dan dilakukan pemerasan menggunakan kain saring sampai kadar air sekitar $80 \%$, selanjutnya memasukan kedalam silent cutter kemudian dilakukan penambahan STPP (Sodium tripholyphosphate) $0,5 \%$ dan gula 4\%. Surimi ikan bandeng yang telah dihasilkan dikemas dengan plastik polietilene dan dibekukan kedalam freezer suhu $-20^{\circ} \mathrm{C}$.

\section{Prosedur Uji Lipat (Folding Test) dan Uji Gigit (Teeth cutting Test) (Suzuki, 1981)}

Prosedur uji lipat dan uji gigit diawali dengan menyiapkan sampel (S1, S2, dan S3). Menimbang masing-masing sampel sebanyak $300 \mathrm{~g}+$ garam 3\% dimasukan kedalam food processor \pm 5 menit sampai diperoleh pasta surimi. Selanjunya pasta surimi dimasukan kedalam alat pencetak dengan diameter 25 $\mathrm{mm}$ dan merebus dengan dua tahap yaitu tahap pertama $40^{\circ} \mathrm{C}$ selama 20 menit dan tahap kedua $90^{\circ} \mathrm{C}$ selama 20 menit. Selanjutnya mendinginkan sampel pada suhu dingin $\pm 5^{\circ} \mathrm{C}$ selama 5 menit dan selanjunya sampel didiamkan pada suhu ruang selama 24 jam sebelum diuji dengan tujuan untuk mendapatkan suhu yang sama dengan suhu ruang.

\section{Prosedur Pembuatan Sosis}

Prosedur pembuatan sosis ini dilakukan dengan tahap-tahap sebagai berikut: terlebih dahulu dilakukan penyiapan dan penimbangan bahan pembuatan sosis berdasarkan perlakuan (S1, S2, dan S3) kemudian memasukan kedalam silent cutter untuk dilakukan pengadonan. Adonan harus dimasukan kedalam silent cutter dimana putaran pisau diatas $3000 \mathrm{rpm}$ sehingga diperoleh adonan elmusi. Selanjutnya penambahan bumbu-bumbu yaitu garam, gula, merica, pala, jahe, putih telur, minyak, es batu dan STPP (Sodium tripholyphosphate) 0,5\% dan tepung tapioka. Tahap selanjutnya memasukan adonan kedalam suffer (alat pencetak sosis) agar adonan masuk kedalam casing (selonsong) dengan diameter $1 \mathrm{~cm}$ dengan panjang $12 \mathrm{~cm}$ pada tiap batang sosis. Adonan dalam casing dibuat sedikit padat agar dihasilkan sosis yang tampak menyatu dengan selonsong dan diikat dengan tali. Memasukan sosis kedalam panci untuk dilakukan perebusan selama 60 menit pada suhu $70-80{ }^{\circ} \mathrm{C}$. Sosis ikan bandeng yang telah matang dilakukan analisis sensorik dan kimia (proksimat) 


\section{Uji Sensorik}

Uji sensorik ini bermaksud untuk mengetahui kualitas produk sosis ikan dengan menggunakan pancaindra panelis. Penilaian sensorik meliputi aroma (aroma khas ikan), odor (amis tidak menyenangkan), warna, berongga, shiness (mengkilap), kekenyalan, hardness (keras), juiciness, umami (gurih, enak).

Uji sensorik dilakukan dengan mengisi lembar schore sheet panelis. Lembar isian schore sheet diisi oleh panelis yang berjumlah sebanyak 20 orang yang telah melewati tahap training panelis, sehingga panelis yang digunakan dalam penelitian ini adalah panelis semi telatih, panelis memberikan skor sesuai tanggapan panelis terhadap produk sosis ikan.

\section{Analisis Kimia}

Analisis kimia menggunakan metode AOAC (Association of Official Analytical Chemists), 2005 dimana kadar air dan kadar abu dianalisis dengan metode thermogravimetri, kadar protein dengan metode Biuret dan kadar lemak dengan metode Soxhlet.

\section{HASIL DAN PEMBAHASAN Karakteristik Fisik Bahan Baku Sosis Ikan Bandeng}

Hasil karakteristikfisik bahan baku sosis ikan bandeng meliputi uji lipat (folding test) dan uji gigit (teeth cuting test) dapat dilihat pada Tabel 1.

Tabel 1. Hasil karakteristik fisik bahan baku sosis ikan bandeng

\begin{tabular}{lccc}
\hline No & Bahan Baku & \multicolumn{2}{c}{ Deskriptif } \\
\cline { 3 - 4 } & Surimi & $\begin{array}{c}\text { Grade AA (tidak retak jika } \\
\text { dilipat seperempat lingkaran) }\end{array}$ & U (daya gigit kuat) \\
\hline 1. & $\begin{array}{c}\text { Kombinasi surimi dan } \\
\text { daging ikan cincang }\end{array}$ & $\begin{array}{c}\text { Grade AA (tidak retak jika } \\
\text { dilipat seperempat lingkaran) }\end{array}$ & 7 (daya gigit agak kuat) \\
\hline 2. & & \\
\hline 3. & Daging ikan cincang & $\begin{array}{c}\text { Grade A (tidak retak jika dilipat } \\
\text { setengah lingkaran) }\end{array}$ & 6 (daya gigit diterima) \\
\hline
\end{tabular}

Hasil uji lipat pada bahan baku sosis ikan diperoleh tidak adanya retakan pada sampel bahan baku S1 (100\% surimi) dan S2 (50\% surimi : $50 \%$ daging ikan cincang) meskipun sampai pelipatan seperempat akan tetapi pada sampel S3 (100\% daging ikan cincang) terdapat retakan pada pelipatan seperempat. Hal ini disebabkan karena dilakukan leaching sebagaimana diketahui bahwa pada sampel S1 (100\% surimi). Namun pada sampel S2 (50\% surimi : $50 \%$ daging ikan cincang) pada sebagian bahan baku surimi dilakukan proses leaching. Namun demikian tetap menunjukan kekenyalan yang tinggi terbukti sampel sampai pelipatan 4 kali tidak memperlihatkan adanya keretakan, yang berarti meskipun hanya memiliki $50 \%$ surimi (mengalami treatmen leaching) sampel sudah mampu menunjukan kekenyalan sebagaimana yang menggunakan surimi $100 \%$. Selain uji lipat untuk mengetahui tingkat kekenyalan juga menggunakan uji gigit. Dimana pada uji gigit diperoleh nilai 8 pada bahan baku $100 \%$ surimi, 7 pada sampel 50\% surimi : $50 \%$ daging ikan cincang dan 6 untuk sampel 100\% daging ikan cincang.

Kekenyalan yang tinggi pada $100 \%$ surimi ini disebabkan oleh leaching yang memicu meningkatnya kekenyalan (jellinity). Sebagaimana pada uji lipat, perlakuan S1 (100\% surimi) pada uji gigit juga memiliki tingkat kekenyalan yang tinggi yaitu daya gigit kuat (8). Pada perlakuan $50 \%$ surimi : $50 \%$ daging ikan cincang memiliki tingkat kekenyalan daya 
gigit agak kuat (7) sedangkan perlakuan S3 (100\% daging ikan cincang) daya gigit diterima (6). Hal ini didukung oleh pernyataan Chaijan et al., (2014) dalam Wijayanti et al., (2012) menyatakan dengan leaching yang tepat protein sarkoplasma bisa terbuang sehingga protein miofibril bisa terkonsentrasi dan dapat berperan penting dalam pembentukan gel.

\section{Uji Sensorik}

Tabel 2. Rerata atribut sensorik sosis ikan bandeng dengan perlakuan S1 (100\% surimi), S2 (50\% surimi : 50\% daging ikan cincang) dan S3 (100\% daging ikan cincang)

\begin{tabular}{|c|c|c|c|c|}
\hline \multirow[t]{3}{*}{ No } & \multirow{3}{*}{$\begin{array}{l}\text { Atribut } \\
\text { sensorik }\end{array}$} & \multicolumn{3}{|c|}{ Perlakuan } \\
\hline & & S1 & $\mathrm{S} 2$ & S3 \\
\hline & & Surimi & $\begin{array}{c}\text { Daging ikan cincang : } \\
\text { surimi }\end{array}$ & Daging ikan cincang \\
\hline 1 & Aroma & 5,4 (agak lebih tercium) & $\begin{array}{l}\text { 5,6 (agak lebih } \\
\text { tercium) }\end{array}$ & 5,8 (agaklebih tercium) \\
\hline 2 & Odor & 6,7 (agak lebih tercium) & $\begin{array}{l}6,7 \text { (agak lebih } \\
\text { tercium) }\end{array}$ & 5,2 (agak lebih tercium) \\
\hline 3 & Warna & $\begin{array}{l}5,25 \text { (cream sedikit } \\
\text { terang) }\end{array}$ & 4,45 (cream) & $\begin{array}{l}3,25 \text { (cream sedikit } \\
\text { coklat) }\end{array}$ \\
\hline 4 & Berongga & 4,9 (agak berongga) & 5,8 (lebih padat) & 5,5 (lebih padat) \\
\hline 5 & Shiness & 5,4 (mengkilap) & 3,5 (agak mengkilap) & 2,7 (tidak mengkilap) \\
\hline 6 & Kekenyalan & 5,5 (kenyal) & 5,2 (kenyal) & 4 (agak kenyal) \\
\hline 7 & Hardness & 2,4 (tidak keras) & 3,8 (agak keras) & 6,5 (keras) \\
\hline 8 & Juiciness & 5,6 (terasa juicy) & 3,9 (sedikit kering) & 2,3 (kering) \\
\hline 9 & Umami & 6 (terasa umami) & 5,4 (terasa umami) & $\begin{array}{l}4,8 \text { (sedikit terasa } \\
\text { umami) }\end{array}$ \\
\hline
\end{tabular}

\section{Aroma}

Berdasarkan Tabel 2 diperoleh nilai rataan uji sensorik aroma pada perlakuan S1 (100\% surimi) sebersar 5,4 (agak lebih tercium), S2 (50\% surimi : $50 \%$ daging ikan cincang) sebesar 5,6 (agak lebih tercium) dan perlakuan S3 (100\% daging ikan cincang) sebesar 5,8 (agak lebih tercium). Hal ini diduga karena pada semua perlakuan sosis ikan bandeng tidak ada perbedaan pemberian komposisi bumbu-bumbu dan lama waktu perebusan.Sesuai dengan pernyataan Nurjannah et al., (2005) yang menyatakan adanya komponen volatil yang terbentuk pada proses pemanasan (pengukusan) dari bahan utama dan bumbu-bumbu yang sama sehingga tidak menyebabkan perbedaan aroma.

\section{Odor}

Berdasarkan Tabel 2 diperoleh nilai rataan uji sensorik odor pada perlakuan S1 (100\% surimi) sebersar 6,7 (agak lebih tercium), S2 (50\% surimi : 50\% daging ikan cincang) sebesar 6,7 (agak lebih tercium) dan perlakuan S3 (100\% daging ikan cincang) sebesar 5,2 (agak lebih tercium). Hal ini diduga bisa dipengaruhi oleh kadar air dari daging ikan maupun jumlah bumbu-bumbu yang dimasukan dalam adonan sosis ikan. Keberadaan kadar air dalam daging ikan cincang maupun surimi akan membuat campuran bumbu-bumbu yang ditambahkan semakin homogen dan akan membantu proses penguapan sehingga membantu mengurangi bau dari bahan baku maupun bumbu-bumbu pada formulasi sosis ikan yang dibuat. 


\section{Warna}

Berdasarkan Tabel 4. Diperoleh nilai rataan uji sensorik warna pada perlakuan S1 (100\% surimi) sebersar 5,25 (cream sedikit terang), S2 (50\% surimi : $50 \%$ daging ikan cincang) sebesar 4,45 (cream) dan perlakuan S3 (100\% daging ikan cincang) sebesar 3,25 (cream sedikit terang).Hal ini diduga karena bahan baku yang digunakan pada perlakuan S1 (100\% surimi) dan S2 (50\% surimi :50\% daging ikan cincang) dilakukan leaching sehingga pigmen darah, lendir, kotoran pencernaan terbuang pada proses leaching. Sedangkan pada perlakuan S3 (100\% daging ikan cincang) tidak dilakukan proses leaching sehingga darah, lemak, lendir yang terdapat pada daging membuat warna sosis cream sedikit coklat. Sesuai dengan pernyataan Elviera (1998) bahwa pada saat pemasakan warna bahan pangan atau produk pangan dapat mengalami perubahan misalkan menjadi lebih cerah. Hal ini disebabkan hilangnya sebagian pigmen akibat pelepasan cairan pada proses pemasakan atau pengolahan sehingga intensitas warna semakin menurun.

\section{Berongga}

Berdasarkan Tabel 2 diperoleh nilai rataan uji sensorik berongga pada perlakuan S1 (100\% surimi) sebersar 4,9 (agak berongga), S2 (50\% surimi : 50\% daging ikan cincang) sebesar 5,8 (lebih padat) dan perlakuan S3 (100\% daging ikan cincang) sebesar 5,5 (lebih padat). Hal ini diduga karena pada saat pengisian adonan kedalam selonsong tidak ada udara yang terjebak pada sosis ikan. Apabila terdapat udara maka menusuk bagian sosis yang mengandung udara dengan jarum steril agar adonan dapat memadat dalam selonsong.

\section{Shiness}

Berdasarkan Tabel 2 diperoleh nilai rataan uji sensorik shiness pada perlakuan S1 (100 \% $\quad$ surimi) sebesar 5,4 (mengkilap), S2 (50\% surimi : 50\% daging ikan cincang) sebesar 3,5 (agak mengkilap) dan perlakuan S3 (100\% daging ikan cincang) sebesar 2,7 (tidak mengkilap). Hal ini diduga karena bahan baku pembuatan sosis ikan bandeng pada perlakuan S1 (100\% surimi) dilakukan leaching sehingga darah yang dapat membuat bahan baku berwarna putih mengkilap. Perlakuan S2 $(50 \%$ surimi : $50 \%$ daging ikan cincang) sebagian dari bahan baku yang digunakan yaitu daging ikan cincang tidak dilakukan leaching sehingga darah yang terdapat pada daging mempengaruhi atribut sensorik pada sosis ikan.

\section{Kekenyalan}

Berdasarkan Tabel 2 diperoleh nilai rataan uji sensorik kekenyalan pada perlakuan S1 (100\% surimi) sebesar 5,5 (kenyal), S2 (50\% surimi : 50\% daging ikan cincang) sebesar 5,2 (kenyal) dan perlakuan S3 (100\% daging ikan cincang) sebesar 4 (agak kenyal). Hal ini diduga karena ikan yang digunakan dalam bahan baku sosis ikan dalam kondisi segar dan dalam proses penyiangan dengan suhu yang rendah. Selain itu, penambahan STPP sebanyak $0,5 \%$ membantu meningkatkan kekenyalan pada produk sosis ikan. Hal ini sesuai dengan pernyataan Amano (1965), menambahkan polifosfat pada gel ikan mentah bertujuan memperbaiki kekenyalan pada produk akhir.

Nampak dari hasil yang ditunjukan pada uji fisik bahan baku sosis (uji lipat dan uji gigit) berhubungan erat dengan hasil yang ditunjukan pada uji sensorik atribut kekenyalan sosis ikan. Sampel bahan baku $100 \%$ surimi menunjukan tingkat kekenyalan yang lebih tinggi meskipun bahan baku pada uji lipat sampel $100 \%$ surimi dan $50 \%$ surimi : $50 \%$ daging ikan cincang memiliki kualitas grade AA (tidak retak jika dilipat seperempat lingkaran)dan uji gigit menunjukan tingkat daya gigit yang berbeda yaitu $100 \%$ surimi dengan daya gigit kuat dan 50\% surimi : 50\% daging ikan cincang menghasilkan daya gigit agak 
kuat tetapi menunjukan tingkat kekenyalan yang berbeda setelah dilanjutkan pengolahan sebagai produk sosis.

\section{Hardness}

Hasil penelitian pada Tabel 2 diperoleh nilai rataan uji sensorik hardness pada perlakuan S1 (100\% surimi) sebesar 2,4 (tidak keras), S2 (50\% surimi : 50\% daging ikan cincang) sebesar 3,8 (agak keras) dan perlakuan S3 (100\% daging ikan cincang) sebesar 6,8 (keras). Hal ini sejalan dengan uji lipat pada sampel bahan baku $100 \%$ surimi, sampel $50 \%$ surimi : $50 \%$ daging ikan cincang dengan uji lipat grade AA dan $100 \%$ daging ikan cincang dengan grade $\mathrm{A}$. Uji gigit pada ketiga sampel bahan baku juga menunjukan tingkatan nilai yang berbeda yaitu $100 \%$ surimi (daya gigit kuat), 50\% surimi : $50 \%$ daging ikan cincang (daya gigit agak kuat) dan $100 \%$ daging ikan cincang (daya gigit diterima) tetapi menunjukan tingkat hardness yang berbeda setelah diolah lebih lanjut menjadi sosis ikan.

\section{Juiceness}

Berdasarkan Tabel 2 diperoleh nilai rataan uji sensorik juiceness pada perlakuan S1 (100 \% surimi) sebesar 5,6 (terasa juicy), S2 (50\% surimi : 50\% daging ikan cincang) sebesar 3,9 (sedikit kering) dan perlakuan S3 (100\% daging ikan cincang) sebesar 2,3 (kering). Hal ini diduga perbedaan kandungan kadar air dari masing-masing perlakuan. Juiciness dipengaruhi oleh kemampuan komponen dalam sosis untuk mempertahankan cairan (dalam hal ini air bebas maupun minyak) saat proses penekanan. Semakin besar jumlah cairan yang keluar saat proses penekanan maka semakin juicy sosis tersebut.

\section{Umami}

Berdasarkan Tabel 2 diperoleh nilai rataan uji sensorik umami pada perlakuan S1 (100 \% surimi) sebesar 6 (terasa umami), S2 (50\% surimi : 50\% daging ikan cincang) sebesar 5,4 (terasa umami) dan perlakuan S3 (100\% daging ikan cincang) sebesar 4,8 (sedikit terasa umami). Hal ini disebabkan karena perlakuan $100 \%$ surimi dilakukan penambahan ekstrak jamur merang sebanyak 12 gram dan 6 gram pada perlakuan $50 \%$ surimi : $50 \%$ daging ikan cincang. Tetapi pada perlakuan 100\% daging ikan cincang tidak dilakukan penambahan ekstrak jamur merang. Namun demikian, pada perlakuan $100 \%$ daging ikan cincang masih terasa umami karena pada perlakuan tersebut tidak dilakukan proses leaching sehingga protein (asam amino) yang terdapat pada daging ikan cincang tidak terbuang.

\section{Analisis kimia Sosis Ikan Bandeng}

Tabel 3. Hasil analisis kimia sosis ikan bandeng berdasarkan berat kering

\begin{tabular}{llcccc}
\hline \multirow{2}{*}{ No } & Parameter & \multicolumn{4}{c}{ Sampel } \\
\cline { 3 - 5 } & & $\mathrm{S} 1(\%)$ & $\mathrm{S} 2(\%)$ & $\mathrm{S} 3(\%)$ & $\mathrm{SNI}$ \\
\hline 1. & Kadar air & $64,19(\mathrm{~b} / \mathrm{b})$ & $63,21(\mathrm{~b} / \mathrm{b})$ & $58,96(\mathrm{~b} / \mathrm{b})$ & Maks 68,0 \\
2. & Kadar abu & 5,9 & 6,8 & 6,22 & Maks 2,5 \\
3. & Kadar lemak & 19,02 & 19,05 & 19,12 & Maks 7,0 \\
4. & Kadar protein & 34,87 & 45,09 & 48,6 & Min 9 \\
5. & BETN \\
Keterangan : S1 = Surimi 100\%, S2 = 50\% surimi : 50\% daging ikan cincang, S3 = Daging ikan cincang 100\% \\
*SNI (2013)
\end{tabular}

\section{Kadar Air}

Berdasarkan hasil penelitian menunjukkan bahwa kadar air pada sosis ikantertinggi pada bahan baku 100\% surimi yaitu $64,19 \%$ dan terendah pada $100 \%$ daging ikan cincang yaitu 58,96. Hal ini diduga karena proses leaching akan meningkatkan kandungan air. Hal ini 
didukung oleh pernyataan Karthikeyan et al., (2004) menyatakan leaching pada surimi akan meningkatkan kadar air. Selain itu, peningkatan kadar air pada sosis ikan $100 \%$ surimi diduga karena semakin meningkatnya aktivitas protein miofibril dalam mengikat air. Karthikeyan et al., (2006) menambahkan bahwa peningkatan kadar air selama proses leaching kemungkinan disebabkan proses hidrasi oleh protein miofibril.

\section{Kadar Abu}

Berdasarkan hasil analisis pada Tabel 3 kadar abu terlihat bahwa sosis yang terbuat dari $100 \%$ surimi memiliki kadar abu terendah yaitu $5,9 \%$ dan tertinggi pada $100 \%$ daging ikan cincang yaitu $6,22 \%$. Hal ini karena proses leaching surimi akan melarutkan mineralmineral dalam daging sehingga jumlah mineralnya semakin sedikit. Hal ini didukung oleh pernyataan Karthikeyan et al., (2006) bahwa pencucian 3 kali pada surimi threadfin bream meningkatkan kadar air dan menurunkan kadar mineral. Mineral sendiri erat kaitannya dengan kadar abu, karena kadar abu berasal dari mineral atau unsur organik yang terbakar dalam proses pembakaran (Winarno, 1997).

\section{Kadar Lemak}

Berdasarkan analisis kadar lemak dapat dilihat bahwa sosis ikan yang terbuat dari $100 \%$ surimi memiliki kadar lemak terendah yaitu $19,02 \%$ dan tertinggi pada $100 \%$ daging ikan cincang yaitu $19,12 \%$. Rendahnya kandungan lemak pada perlakuan100\% surimi diduga karena lemak yang terdapat pada daging ikan mengapung diatas permukaan air sehingga terbuang pada proses leaching dan pengepresan. Hal ini didukung oleh pernyataan Husni dan Iwan (2002) menyatakan partikel-partikel lemak yang ada saat pencucian daging lumat dengan air dingin terapung dibagian permukaan juga terbuang pada proses leaching sehingga kadar lemaknya menurun. Selain itu, Wijayanti et al., (2012) menyatakan penurunan kadar lemak karena lemak memiliki densitas yang lebih rendah dari air sehingga menyebabkan lemak dapat mengapung di air pencucian dan akan terbuang bersama proses pengepresan. Lemak berat jenisnya lebih rendah sehingga dapat terapung dan ikut terbawa bersama air pencucian. Selain itu, ditambahkan oleh penelitian Hossain et al., (2004) menunjukkan daging lumat yang telah dicuci (surimi) menurun kadar lemaknya dari $3,1 \%$ menjadi $0,63 \%$ pada ikan mas dan $6,8 \%$ menjadi $0,59 \%$ pada ikan patin. Hasil lain menunjukkan kadar lemak surimi ikan sardine menurun dari $14,44 \%$ sebelum dicuci menjadi $4,23 \%$ setelah pencucian 3 kali dan 2,31\% setelah 5 kali pencucian (Karthikeyan et al., 2004).

\section{Kadar Protein}

Berdasarkan hasil penelitian menunjukan bahwa kandungan protein terendah pada $100 \%$ surimi yaitu $34,87 \%$ dan tertinggi pada $100 \%$ daging ikan cincang. Hal ini diduga karena proses leaching pada pembuatan surimi dimana protein terbuang selama proses pencucian sehingga kadar proteinnya menurun. Selain itu, adanya penurunan kadar protein dalam sosis ikan disebabkan oleh larutnya protein sarkoplasma. Sesuai dengan pernyataan Suzuki (1981) bahwa protein sarkoplasma terdapat di dalam sarkoplasma sel otot dan bersifat larut dalam air. Pada penelitian Karthikeyanet al., (2006) mengungkapkan bahwa surimi ikan threadfin bream yang dicuci 3 kali menurun kadar proteinnya hingga 32\% darikadar awal. Penurunan kadar protein ini kemungkinan disebabkan hilangnya protein larut air selama pencucian dan meningkatnya kadar air pada produk akhir (Ismail et al., 2010).

\section{KESIMPULAN}

Perbedaan persiapan bahan baku surimi sosis ikan ikan bandeng menujukan perbedaan yang signifikan warna, shiness, 
hardness, juiceness, namun tidak memberikan pengaruh yang signifikan terhadap uji sensorik aroma, odor, berongga, kekenyalan dan umami. Kadar abu, kadar lemak dan kadar protein meningkat seiring dengan kurangnya konsentrasi surimi dalam bahan baku. Sebaliknya, Kadar air meningkat seiring dengan tingginya konsentrasi surimi dalam bahan baku sosis ikan bandeng.

\section{DAFTAR PUSTAKA}

Agustini, T. W., Fahmi, A. S dan Amalia, U. 2010. Modul Diversifikasi Produk Perikanan. Program Studi Teknologi Hasil Perikanan, Universitas Diponegoro.

Amano, K., 1965. Fish sausage manufacturing. In Fish As Food Vol III. (G. Borgstorm. Ed). Academic Press, New York.

AOAC. 2005. Official methods of analysis. Association of Official Analytical Chemist, Washington DC.

Chaijan, M., Benjakul, S., Visessanguan , W and Faustman. 2004. Characteristics and gel properties of muscle from sardine (Sardinella gibbosa) and mackerel (Rastrelliger kanagurta) caught In Thailand. Food Research Internasional 37: 1021-1030.

Elviera, G. 1998. Pengaruh pelayuan daging sapi terhadap mutu bakso [Skripsi]. Bogor. Fakultas Teknologi Pertanian, Institut Pertanian Bogor.

Ernawati. 2015. Pengaruh perlakuan asap cair terhadap sifat sensori dan mikrostruktur sosis asapikanleledumbo(Clarias gariepinus). Fakultas Pertanian, Universitas Yudharta. Jurnal Kelautan Volume 8, No. 2.
Guenneugues, P dan Morrissey, M. T. 2005.Surimi Resources. CRC Press, Florida.

Husni, A dan Iwan, Y. B. L. 2012. Pencucian mempengaruhi surimi cucut (Carcharinus sp.). Jurnal Perikanan UGM (GMU J. Fish. Sci) IV (2).

Hossain, M. I., Kamal, M. M., Shikha, F.H., Hoque, M. D. S. 2004. Effect of washing dan saltconcentration on the gel forming ability oftwo tropical fish species. Agriculture dan Biology 6 (5): 762-766.

Irianto. H. E. 2007. Dukungan teknologi penyediaan produk perikanan. Badan Riset Kelautan Dan Perikanan Departemen Kelautan Dan Perikanan, Jakarta.

Ismail I, Huda N, Ariffin F, Ismail N. 2010. Effect of washing on the functional properties ofduck meat. Poultry Science 9(6): 556-561.

Junianto. 2003. Teknik Penanganan Ikan. Penebar Swadaya, Jakarta.

Karthikeyan, M., Shamasundar, B.,A, Mathew, S., Kumar, P.R dan Prakash, V. 2004. Physicochemical and functional properties of protein from pelagic fatty fish (Sardinellalongicep) as function of water washing. Food Properties 7(3): 353-365.

Karthikeyan, M., Dileep, A.O., Shamasundar, B.A. 2006. Effect of water washing on thefunctional and rheological properties of proteins from threadfin bream (Nemipterus japonicus) meat. Food Science and Technology 41: 1002-1010.

Martin-Sanchez, A. M., Navarro C., PerezAlvarez, J.A, Kuri, V. 2009. Alternatives for efficient and sustainable production of surimi: A Review.Comprehensive Review in Food Science and Food Safety 8: 359-374. 
Nurjanah., Nitibaskara, R. R dan Madiah, E. 2005. Pengaruh penambahan bahan pengikat terhadap karakteristik fisik otak-otak ikan sapu-Sapu (Liposarcus pardalis). Buletin Teknologi Hasil Perikanan. Vol VIII No 1.

Rostini, I. 2013. Pemanfaatan daging limbah fillet ikan kakap merah sebagai bahan baku surimi untuk produk perikanan. Akuatika Vol. IV. No. 2.

Standar Nasional Indonesia [SNI]. 2013. Sosis Ikan. 7755: 2013, Jakarta.

Suzuki, T. 1981. Fish and Krill Protein in Processing Technologi. Applied Science Publishing Ltd, London.

Suhartini, S dan Hidayat, N. 2005. Olahan ikan segar. Trubus, Surabaya.

USDA National Nutrient Database for Standard Reference. 2013. Milkfish list nutrition.

Widodo, A. 2008. Karakteristik sosis ikan kurisi (Nemipterus nematophorus) dengan penambahan isolat protein kedelai dan karagenan pada penyimpanan suhu chiling dan freezing. PPs Institut Pertanian Bogor, Bogor.

Wijayanti, I., Santoso, J dan Jacoeb, A.M. 2012. Pengaruh pencucian terhadap karakteristik gel surimi ikan lele dumbo (Clarias geriepinus). Saintek Perikanan. Vol. 8. No. 1: 35-36.

Winarno. 1997. Kimia Pangan dan Gizi. 415. PT. Gramedia Pustaka Utama, Jakarta. 